\title{
Social benefits of restoring historical ecosystems and fisheries: alewives in Maine
}

\author{
Loren McClenachan $^{1}$, Samantha Lovell ${ }^{1}$ and Caroline Keaveney ${ }^{1}$
}

\begin{abstract}
Restoration of coastal ecosystems provides opportunities to simultaneously restore historical fisheries and ancillary ecosystem and social benefits that were historically derived from functioning ecosystems. In Maine, dam removal and other ecosystem restoration efforts have positively impacted anadromous fish, with local populations of alewives (Alosa pseudoharengus) rapidly recovering to near historical population abundances in some locations. This research investigates the social benefits conferred by the restoration of habitat connectivity, fish populations, and local small-scale fisheries. Using municipal fisheries data and interviews with stakeholders in coastal Maine, it describes a suite of both direct and indirect benefits: a reversal of the "shifting baselines syndrome" and a motivation to manage fisheries sustainably, diversification of local economies and fisheries, community building and an increased sense of local pride, a demographic broadening of the conservation community, and enhanced ecosystem services and recreational opportunities. As well, it identifies a positive feedback between economic benefits and other social benefits, with revenue earned from alewife fisheries enhancing community engagement and providing motivation for further restoration. Placing ecological restoration efforts into this larger social context - rather than simply evaluating them based on immediate economic benefits-provides a broader framework to assess overall societal benefits derived from restoration efforts.
\end{abstract}

Key Words: ecosystem restoration; historical ecology; new conservation; resilience; shifting baselines; small-scale fisheries; socialecological systems

\section{INTRODUCTION}

Historical ecology has described long-term changes in aquatic ecosystems, documenting population declines for marine and freshwater fish in excess of $90 \%$ (Rosenberg et al. 2005, Humphries and Winemiller 2009). One goal of historical ecology research has been to provide baselines for restoration, as documenting past abundance can both provide quantitative targets and motivate action among community members (McClenachan et al. 2012). In practice, however, restoration of animal populations to past abundances is often not possible due to larger ecosystem changes or inherent biological characteristics of the species itself (Yoshiyama et al. 1998, Marsh et al. 2005). In the eastern United States, industrial decline has facilitated large-scale river restoration, which has resulted in the rapid return of some species of anadromous fish populations, a phenomenon that is perhaps most pronounced in the state of Maine (Lichter et al. 2006). These successful restoration efforts provide an opportunity to assess the benefits of restoring historical ecosystem connectivity and animal populations. Although research on the benefits of ecological restoration has assessed increased biodiversity and ecosystem services (Benayas et al. 2009, de Groot et al. 2013), as well as direct economic benefits (Lewis et al. 2008), the social, nonmarket benefits of restoration are typically overlooked and thus have been consistently underestimated (Aronson et al. 2010, Petursdottir et al. 2013).

Documenting the social benefits of restored ecosystems falls within the realm of "new conservation," defined in part through a focus on identifying and enhancing links among healthy ecosystems, economies, and social structures (Tallis et al. 2008, Kareiva and Marvier 2013, Levin 2014). Although the new conservation paradigm is not universally accepted as the best approach to protecting nature (e.g., Soulé 2013, Cafaro and
Primack 2014, Miller et al. 2014), it provides a useful framework for analysis of restoration in highly altered landscapes. Its applied focus runs parallel to a rise in social-ecological systems (SES) research, which emphasizes the need to more fully describe the reciprocal relationships between humans and ecosystems (Gonzalez et al. 2008, Folke et al. 2010). An important tenet of both new conservation and SES work is that nature can be resilient, which has directed attention toward human-dominated landscapes such as urban and industrial areas. A second tenet of new conservation is that conservation efforts are most effective when they have a broad base of support. Therefore, it advocates finding common ground with groups typically outside the traditional folds of conservation, such as corporations and those involved with natural resource extraction. Likewise, SES research has highlighted links between ecological and social resilience (Folke et al. 2010), the ability of resource users to be stewards of natural resources (Friedlander et al. 2013), and commonalities between ecological fragmentation and social issues such as poverty and cultural disengagement (Cumming 2011).

In coastal regions, one robust SES in the past was small-scale, diversified fisheries (McClenachan and Kittinger 2013). Social benefits of small-scale, diversified fisheries include local empowerment over resource management, the ability for individual fishers to efficiently shift among target species, depending on seasonal abundance and availability, and increased individual profit through direct local sale of the seafood products. Ecological benefits include spreading effort across the ecosystem, thereby reducing pressure on any one fish stock, the ability to target locally abundant species, and decreased energy associated with transporting seafood to the consumer (McClenachan et al. 2014). In stark contrast, modern globalized fisheries systems have eroded both social and ecological integrity, with highly mobile 
fishing fleets resulting in serial depletion of fish populations (Berkes et al. 2006), contributing to widespread overfishing and economic marginalization of coastal communities (Thara Srinivasan et al. 2010).

Fisheries in coastal Maine have reflected these global patterns, characterized at present by extremely low diversity (Steneck et al. 2011) following serial depletion of high-value fisheries (Berkes et al. 2006). Changes over the last three decades have also resulted in a simplification of related SES: concentration of wealth (Bradley 2011), a reduction of diverse fishing rights (Alden 2011), and loss of ecologically important spatial diversity in fish populations (Ames and Lichter 2012). However, Maine also has a strong history of small-scale diversified fisheries and has shown recent momentum back toward these systems (Alden 2011, McClenachan et al. 2014, 2015). Likewise, recent restoration efforts in riverine systems have increased ecological connectivity and fish populations, while also creating opportunities for fisheries diversification. Such postindustrial restoration may not only allow a return of historical ecosystems and fish populations, but also a partial return to the types of preindustrial, small-scale fisheries systems that these rivers supported in the past. This fundamental shift may be both economically and socially important in areas currently characterized by depressed economies and lowered opportunity for community engagement. In this research, we investigate the suite of social benefits conferred by restoring historical fisheries and ecosystems using a case-study approach: alewives in Maine.

\section{Background: alewives in Maine}

Alewives (Alosa pseudoharengus) are small, anadromous herrings ranging from Labrador to South Carolina that migrate upstream each spring to spawn in lakes. In Maine's rivers, alewives are harvested during the spring migration with small-scale gear, including weirs, cast nets, seines, and dip nets. Alewives have been an important source of food since the beginning of human settlement in New England, with 4000-year-old alewife bones identified from middens (Watts 2012). At the time of European settlement, alewives migrated through nearly every coastal watershed in Maine. Colonial fisheries developed in the 1600s, and by the end of the 19th century, annual alewife landings from Maine's river fisheries exceeded 3 million pounds (Smith 1896).

Alewife populations are closely tied to river development. From 1634 to 1850 , industrial dam construction on Maine's rivers reduced access to lake spawning habitat by over $95 \%$, with subsequent population crashes (Hall et al. 2011). This industrial landscape dominated New England's rivers until the early 20th century (Frank 2011). Restoration efforts to benefit alewives began in the 1940s (Rounsefell and Stringer 1945), and over the past two decades, large-scale dam removal and fish passage enhancement have occurred in Maine (Crane 2009, Maine Department of Marine Resources (MDMR) 2011). Local alewife populations have rebounded quickly in response. For example, the Fort Halifax dam in the Sebasticook River (Fig. 1) was removed in 2008; the first cohort of alewives to pass upstream exceeded 1.7 million fish, the largest run on the U.S. east coast in 2009 (MDMR 2009). Such increases are ecologically significant: alewives are the base of marine, freshwater, and terrestrial food webs, so alewife increases may contribute to increases in predator abundance (Lichter et al. 2006). Alewives also act as a prey buffer for endangered Atlantic salmon (Salmo salar), so their increase may facilitate the recovery of an endangered species (Saunders et al. 2006). The increase in alewife population appears to have simultaneously benefited people, as it has resulted in the growth of traditional river fisheries, in some cases reestablishing fisheries in towns lacking fisheries for more than two centuries. Here, we investigate those social benefits.

Fig. 1. Alewife (Alosa pseudoharengus) harvesting locations (water bodies) in Maine, and towns that harvest in each location. The number of interviews conducted in each location is indicated in parentheses. Six interviewees were not associated with a particular town.

\section{Alewife Harvesting Locations and Towns in Maine}

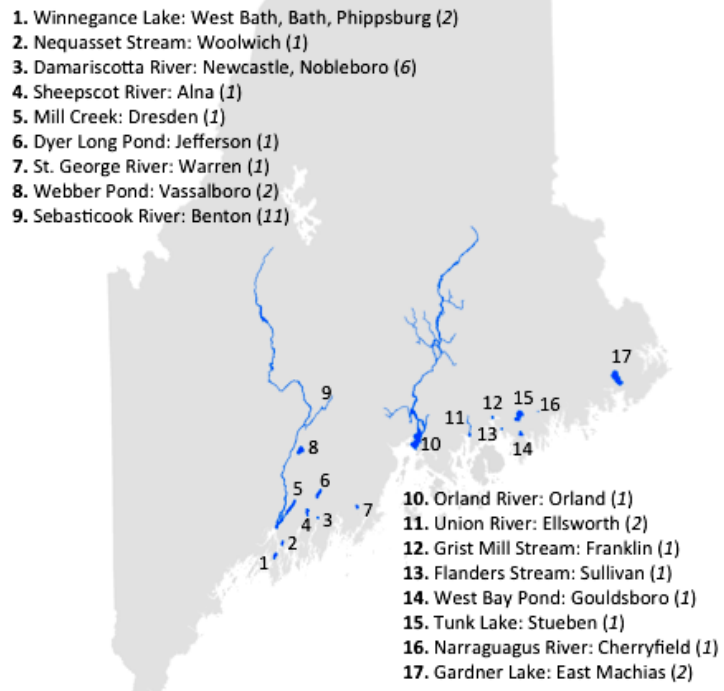

\section{METHODS}

Our goal was to identify social benefits derived from the restored alewife fishery. First, in order to understand recent changes to local fisheries, we collected annual data on alewife landings, firstsale value, and revenue from individual towns for as many years as records existed. Second, to understand how stakeholders viewed these changes, we conducted in-depth interviews with stakeholders. We first identified community members known to be involved with river restoration efforts or alewife harvesting (e.g., those whose restoration work had been featured in local newspapers and local harvesters). We identified subsequent interviewees using a snowball sampling approach, whereby existing interviewees suggest future interviewees from among their acquaintances (Goodman 1961). We conducted interviews in all Maine towns with active alewife fisheries (Fig. 1). The number of interviewees per town ranged from 1 to 11 , with a higher number of interviewees in two towns (Benton and Damariscotta) that have active or recent restoration projects. Stakeholders included town representatives $(n=17)$, alewife harvesters and smokers $(n=5)$, alewife festival volunteers $(n=$ 6), representatives of environmental nonprofits focused on river 
restoration $(n=5)$, residents of towns with active fisheries restoration programs $(n=4)$, state of Maine representatives $(n=$ $2)$, representatives of Native American groups $(n=1)$, and hydroelectric company employees $(n=1)$.

Interviews were semistructured, with open-ended questions allowing varied responses. We first asked a series of questions about local river restoration efforts, perceptions of changes in alewife abundances, and any notable developments in local fisheries. Next, we asked a series of questions about perceptions of benefits that have been derived locally from river restoration, increased alewife populations, and alewife fisheries. We also asked specific questions in each municipality about fishing rights and lease arrangements, and other relevant history or features specific to the fishery in that jurisdiction. Primary questions (Appendix 1) were asked of all interviewees, with follow-up questions as appropriate to individual conversations.

A total of 41 interviews lasting between 10 and 120 minutes were conducted in June and July 2014. Twenty-three interviews were conducted in person, and 18 were conducted over the phone. Each interview was recorded and transcribed; transcripts were used to identify social benefits, which included, but were not limited to, economic benefits. We were interested in understanding how stakeholders identified benefits, so all benefits that we describe were originally reported by respondents. Because questions were open ended, our analysis involved reviewing all responses to identify common themes, grouping responses with similar themes into discrete types of benefits, and placing these grouped responses into a larger context. Wherever possible, we maintain respondents' original wording, in order to directly demonstrate local views on the benefits of river restoration and alewife fisheries.

\section{RESULTS}

We identified five social benefits of restoring historical ecosystem connectivity and alewife fisheries in Maine's rivers:

\section{Unshifted baselines, restored fishing rights, and a second chance at sustainability}

Our interviews demonstrate that restoration can lead to a collective remembering of past states of abundances, enhanced attachment to past and place, and increased sense of well-being. Together, these changes indicate a reversal of the commonly cited shifting baselines syndrome, or the slow loss of ecological integrity that leads first to loss of collective memory about past states of natural abundance and ultimately to a ratcheting down of expectations for the natural world (Pauly 1995). In Maine's rivers, damming and resultant reductions in local alewife populations occurred over centuries and generations of Maine residents. As one interviewee stated, "We have no recollection of what it was like or do we have any appreciation for the vast amount of fish that used to come into these waters." Even when alewives persisted, their range was severely restricted, so that communities lost the understanding of the productive local fisheries that their rivers once supported. As one interviewee said, "If you went out on the street and took a poll [about alewives], you would get a lot of blank stares." Such shifted baselines contribute to a detachment from the natural world and can result in a lost sense of possibility and agency at the personal and community level (MacKinnon 2014).
The process of restoration appears to have triggered a reversal of this shifted baseline, with an increased expectation both for the productivity of natural systems and the ability of community action to achieve conservation success. Among our interviewees, the most commonly mentioned value associated with the restoration of Maine's alewife populations was the personal and communal value of witnessing and contributing to ecological recovery, and the associated feelings of accomplishment from restoring what many regarded as degraded or lost resources. One coastal resident described it as "pretty exciting that with taking dams out, the fish are now able to go up rivers that they haven't been able to go up since World War II. In the last two years, we have gotten one million fish. We haven't seen those numbers since the '30s." Some pointed to the local importance of a fishery that goes back "before Maine was a state." For others, the cultural connection had not been lost, and instead, recent gains served to enhance family and community traditions, such as two sisters who are fourth-generation alewife smokers. Some noted that alewife restoration was personally significant to the older town residents. As one smokehouse owner stated, "Anybody who is 55, 60, and over can remember a time in their childhood of either fishing and seeing the alewives or stopping at a general store and seeing them smoked and eating them." This common theme of connection to the past demonstrates the cultural value of alewives in many small Maine towns (Fig. 2A). As well, it demonstrates that although the collective memory of high natural productivity was temporarily lost, the cultural connection to the past never entirely disappeared, facilitating a reversal of the shifting baselines syndrome. Together, these responses demonstrate the enhancement of personal connection to place and community that can come from restoring historically abundant fish populations.

Fig. 2. A representation of various aspects of alewives (Alosa pseudoharengus) in Maine. (A) Two men smoking alewives in East Machias, Maine (ca. 1980, courtesy of Bucky Davis). (B) A fish trap in Stueben, Maine, demonstrating the small scale of the alewife fishery. (C) A sign advertising smoked alewives in Damariscotta Mills, Maine. (D) A child attending the Benton alewife festival in 2014. (E) Participants of the Damariscotta Mills alewife festival (courtesy of Russ Williams). (F) A restored fishway in Damariscotta Mills.

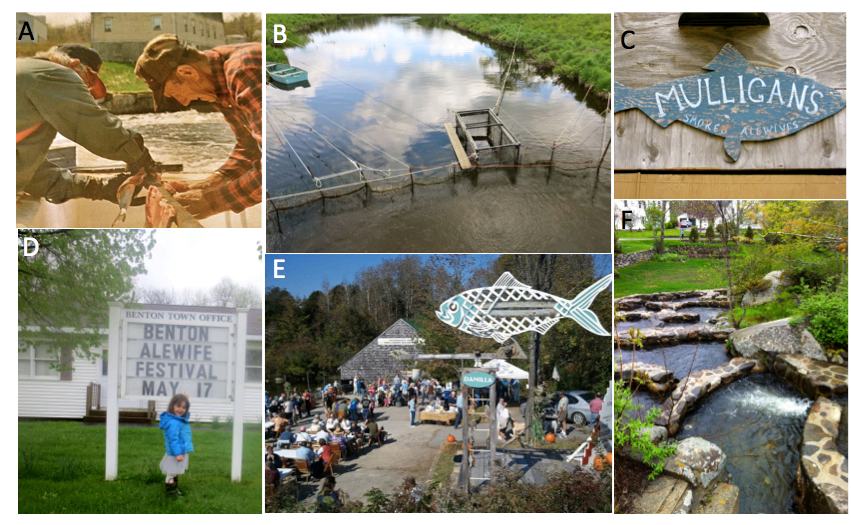


In some rivers, alewife runs have been continuous through time, but in others, recent river restoration has facilitated new fisheries with the opportunity to engage with local fisheries history. Management structures for these historically decentralized fisheries remain intact, enabling reassertion of local rights, a significant empowering device for change. For example, fisheries were traditionally managed at a town level, with deeds that can be traced back to before the Revolutionary War. In some cases, this left a historical precedent for fisheries rights without a harvestable resource. In Benton, one such town on the Sebasticook River (Fig. 1), the 2008 removal of a downstream dam resulted in an active alewife run for the first time in over 200 years. In anticipation of this potential fishery, community members petitioned the state of Maine for the reestablishment of historical harvesting rights, which required documenting the past fishery. To do so, residents collected historical anecdotes describing local alewife harvesting, including a traveler's account that "thousands of barrels" were taken on the Sebasticook River "just above the falls" [i.e., in Benton] in 1796 (Coffin 1855). The petition was successful, and municipal fishing rights were officially restored in 2009 .

These ties to history also provide a motivation for managing the fishery sustainably, giving the fishery a second chance for sustainability informed by past mistakes. A town official indicated "there have been crashes, [so] we must demonstrate each year that this run is sustainable." Alewife fisheries were historically managed at the town level, but a highly localized management structure cannot ensure sustainability of migratory species. In 2007, individual harvesters self-organized as the Alewife Harvesters of Maine and are now part of a larger comanagement of alewife river fisheries structure that involves harvesters, municipalities, the state of Maine, and the federal Atlantic States Marine Fisheries Commission. Maine's comanagement structure and restoration has been described as successful. One harvester said, "The managers [in other states] talk about restoration, they look what Maine has done."

Diversification and enhancement of local economies and fisheries A second benefit of restored alewife fisheries is enhancement of local economies and the diversification of local fisheries. Over the past 20 years, the economic diversity of marine resources harvested in Maine has declined by almost $70 \%$, with more than $80 \%$ of the value of Maine's fisheries derived from one species, American lobster (Homarus americanus). This lack of diversity has strong implications for social resilience, with warnings that a collapse of the lobster fishery would result in severe social disruption in coastal Maine (Steneck et al. 2011). Efforts to diversify Maine's fisheries beyond lobster have focused on the resurrection of small-scale fisheries that return the most benefits to the local community (Alden 2011). Alewife fisheries contribute to this goal. Harvesting is small in scale; one town clerk described it as "a small bunch of nets set up, it is easy to overlook, and most people wouldn't realize it is a fishery" (Fig. 2B). Management and consumption are also local. Alewife harvesters enter into harvesting contracts with individual towns, which place a strong value on maintaining local benefits; one clerk mentioned that their town had failed to renew a harvester's licence because the community "saw a lot of our fish leaving the town... [and] we want to keep everything local." The primary use for Maine alewives is bait for spring lobster fishing, with direct sale from alewife harvesters to lobster fishers. A small but growing niche market for local human consumption also exists, which increases the value by nearly 15 times compared with the bait fishery. Thirteen active alewife smokehouses sell smoked fish directly to local residents (Fig. 2C), and smokehouse owners noted an increase in local interest in eating alewives, reporting that they "did not have enough for everyone" and that they "sell out usually within a day." As one stakeholder said, "That's a good diversification and that's a good added value for Maine."

Although small in scale, alewives provide economic and social benefits at the municipal level both directly by providing revenue to cash-strapped municipalities and indirectly by helping to create a positive feedback among restoration, financial benefits, and community involvement. Individual towns with harvesting rights lease those rights to local harvesters. Particularly for small towns with limited tax bases, leased rights can provide a substantial contribution to town budgets, reducing property tax burdens, and providing fiscal stability. Whereas revenue is split between harvesters and municipalities in various ways (Table 1), in most towns, municipal revenue is directly proportional to the size of the harvest, with average revenue increasing since the 1990s (Fig. 3A). A town official remarked, "The financial benefit in a small town, limited in revenue from real estate, that's a big deal." Another described the $\$ 14,000$ gained from the fishery as "big money for us." In six municipalities, funds are used exclusively for river restoration and management of the alewife fishery, such as a $\$ 37,000$ project to rebuild a fishway. Other towns use the revenue to improve infrastructure. In one "the revenue funded a stone walkway by the Grist Mill Stream, which is now a beautiful location, people take pictures there." In another, the funds were used to build a new gymnasium and in others, the additional income "goes to schools that are failing... and to help lower property taxes," effectively spreading benefits among town residents.

Table 1. The variety of ways that municipalities split the revenue gained by the alewife (Alosa pseudoharengus) harvest between the town and the harvester.

\begin{tabular}{lcc}
\hline \hline Towns & $\begin{array}{c}\text { Town } \\
\text { percentage }\end{array}$ & $\begin{array}{c}\text { Harvester } \\
\text { percentage }\end{array}$ \\
\hline Damariscotta Mills & 100 & 0 \\
Gouldsboro & 75 & 25 \\
Ellsworth and Woolwich & 50 & 50 \\
Warren & 40 & 60 \\
Vassalboro, Benton, and Jefferson & 33.3 & 66.6 \\
Cherryfield, Bath, West Bath, and & 25 & 75 \\
Phippsburg & 20 & 80 \\
Orland & 10 & 90 \\
Alna & 0 & 100 \\
Dresden & & \\
Sullivan, Steuben, Franklin, and East & Fixed rate & \\
Machias & $(\$ 400-5,470)$ & \\
& & \\
\end{tabular}


Fig. 3. Increases in alewife (Alosa pseudoharengus) populations and fisheries in Maine. (A) Mean revenue to Maine towns derived from leasing alewife harvesting rights, 1994-2014. Error bars represent standard error. (B) Revenue to harvesters and the municipality in a long-term alewife-harvesting town, Warren, Maine, 1995-2012. (C) Numbers of alewives harvested and passed upstream in the Damariscotta River, 1987-2013.

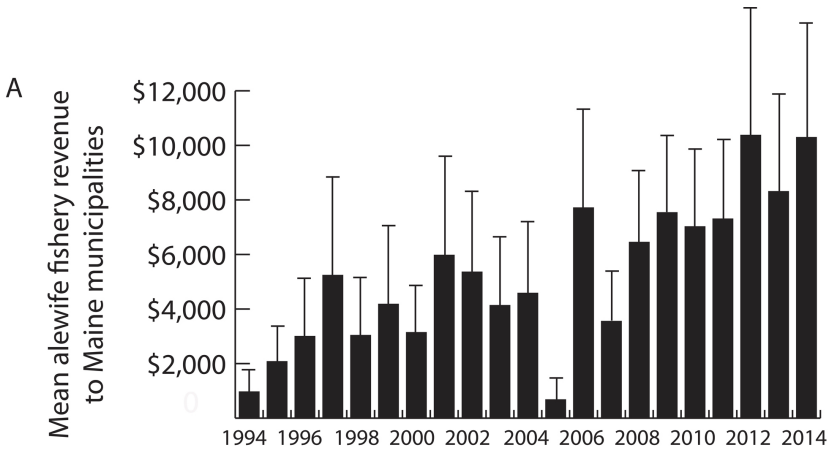

B
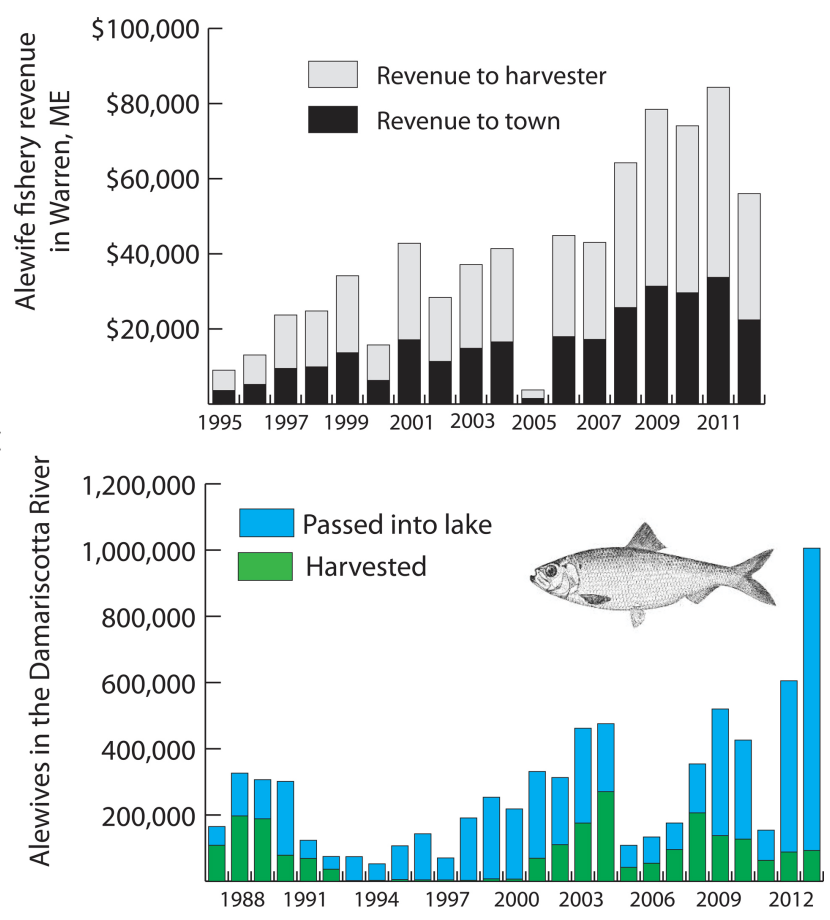

The restoration of fish populations has also created seasonal harvesting jobs and extended the summer tourism season in certain towns. The alewife-harvesting season spans 5-7 weeks from the end of April to the beginning of June, a short, intense fishing season, which requires harvesters to employ other residents. A stakeholder remarked "it brings people out and puts money in their pockets in the spring of the year. Most Mainers have seasonal jobs." As well, in some towns, the fishery draws in tourists before the summer tourist season begins. In one town, a representative said, "the economic benefits are huge...People come and they need a place to stay and eat." In some locations, the fish restoration infrastructure has become a tourist attraction throughout the year. In Damariscotta Mills, a town park surrounding an artistically designed restoration site (Fig. 2F), tourists visit "not only in the spring but in the summer and fall and lot of these people stay at local inns, eat at restaurants, buy stuff from stores, so there's certainly an economic benefit to the area." Although direct revenue, job creation, and tourism are clearly economic benefits, the perception of a financial benefit also provides incentive to invest in restoration, thereby contributing to broader social benefits. These tangible benefits from a local fish migration and fishery help to demonstrate the value of restoration to community members, which may ultimately increase community engagement and interest in restoration efforts.

\section{Community building in postindustrial towns}

A third benefit of the restored alewife fishery that stakeholders identified is an increased sense of place and pride in the community. Many alewife-harvesting towns historically had industrial-based economies, relying on mills as both a source of income and an identity. As mills closed, restoring the alewife fishery has provided a partial substitute to define the region. A stakeholder commented that the alewife run is "one of those very nice regional, cultural phenomena that helps someone from one area to define themselves," that the "harvest gives the town some community feel - an identity," and "adds culture." An individual active in promoting tourism around alewives said "I thought that little towns like Benton really have a hard time putting themselves on the map... and so I said "what do we have that is unique here? 'And hey, this alewife migration is one." Noting this effective local branding, another stakeholder reported, "I've met a ton of people over the years [who] ask where I'm from and I say Damariscotta Mills... and they say 'Oh the fish ladder!'" Several stakeholders noted the increased sense of pride associated with the fishery and restoration can motivate conservation action. An alewife harvester stated, "Pride in your community is worth a lot. Pride, you get involvement, and with more involvement you get people who are willing to spend more money, which supports the restoration and the ecosystem." A school official concurred, "there's a sense of pride in the community when they know that the alewives are being harvested in the right way... anytime you can get the community directly involved in something, it increases awareness and they have ownership of that, and I think that's important."

The fishery also physically brings people together, as they gather to watch the spring migration and harvest (Fig. 2E). Many of the towns that currently harvest alewives lack a downtown where the community can interact and socialize, such that the harvest site is a source of curiosity and interest among locals. One town official said, "the area for the harvest is quite social-[it's] a tradition for young people to go down and watch." In another town, the fishery was described as a "spectator sport" and "people like to go stand at the bridge and watch them take the fish out. It becomes really congested over there at some points." Another town official was surprised at how many visitors frequent their harvest site. Such gatherings can build camaraderie. An alewife harvester said, "it's been a long cold winter... everyone gets out and can interact...it's also the interaction of people who haven't seen each other for a year. Socially it's a good thing." Such interaction may also bring people together and ease other social tensions. A harvester noticed that, "It gets guys out who normally wouldn't talk to each other because they are worried that they are 
cutting each other's [lobster] traps. But they can talk and make peace and not cut each other's traps this year."

Alewife festivals in two of the harvesting towns, Damariscotta and Benton, provide a means for the communities to celebrate both the alewife and the town (Fig. 2D, E). Festivals include opportunities to view migrating alewives, eat smoked alewives, and participate in community dinners and discussions. A Benton selectman noted "People were hungry to embrace something that involved the entire community and to see their friends out and about. We don't have a downtown - it created a downtown for the day." Festivals in both towns draw between 1000 and 1500 attendees, which represents $50-75 \%$ of the populations of these small towns. A festival volunteer noted that, "it was the first time the whole town had been together, and they thought it was great. Things like that, when you rally a rural community, they start thinking about things in terms of community." Maine's alewife festivals share similarities with other, longer-standing anadromous fish festivals along the eastern seaboard, but notably, in many other locations, fish populations are decreasing rather than increasing. River herring festivals are celebrated in North Carolina, despite the local closure of the fishery (Overton 2013), and when American shad (Alosa sapidissima) populations on the Hudson River declined, closing in 2010, shad festivals substituted purchased salmon for shad (Severson 2008, Kahnle and Hattala 2010). In contrast, Maine's alewife festivals are explicitly linked to river restoration, with tours of the restoration sites, opportunities to sample locally harvested alewives, and public lectures by members of the restoration community held alongside other community events.

Finally, the alewife fishery provides opportunities for youth and community engagement around restoration. In one town, the municipal harvesting contract sets aside a certain amount of alewives for local students to learn the harvesting and smoking process and take the smoked alewives home to their parents and grandparents who "go crazy over the alewives." These programs connect students to local heritage while also providing an opportunity to discuss long-term change and environmental successes. A volunteer noted that he takes "high school and junior high school kids out on the river and talk about the environment, Clean Water Act, and about how dirty the rivers used to be." A restoration leader commented that, "there were a lot of citizens who, if it weren't for the existence of alewives wouldn't have felt the connection to the river and to nature." Another stakeholder said, "It's just this idea that you can bring a river back and rallying people around that. The Sebasticook is now one of the leaders in the East Coast for river restoration. Now the 'nasty Sebasti' is a really gorgeous place. It's a way to get people excited about the environment and make them feel like they can make a difference." The tangible benefit of alewife fisheries that are derived from restored rivers helps to align community and ecological benefits, providing multiple means for engaging the community and an example of success to potentially motivate larger actions.

\section{Broadening the community of conservationists}

The restoration of the alewife fishery has broadened the community of conservationists, helped to align business and conservation interests, and increased community involvement with restoration, all facets of new conservation (Tallis et al. 2008,
Kareiva and Marvier 2013). One self-identified group of conservationists is the harvesters themselves. A harvester described himself as a "a [political] conservative but also an environmentalist" noting that "those two words don't always go together." Providing harvesters with exclusive long-term harvesting contracts - along with a clear connection between habitat restoration and fish abundance - incentivizes stewardship among alewife harvesters. Although the link between privatization in fisheries and resource stewardship is far from clear (Gilmour et al. 2012), individual alewife harvesters benefit personally from their own habitat restoration and stewardship efforts, and interviewees reported that harvesters were invested in this process. One harvester with a 10-year contract did not harvest for the first 2 years, instead focusing on improving local fish passage. A town clerk explained the harvester was "active in making sure that the run is good and keeping the stream more productive." Similarly, a town official in Sullivan commented that "some years [the harvesters] didn't harvest, and instead cleaned the brook out so later years would be better, showing stewardship and understanding of the ecological system." One harvester explained, "We do right in Maine, my peers make sure we harvest sustainably."

A second group brought into conservation by river restoration is hydroelectric operators. In Maine, many legacy dams exist that produce little or no power, which stakeholders pointed to as "a real opportunity" to increase fish passage while streamlining the power generation infrastructure. A harvester noted, "It's working with hydro companies well that will make the fisheries up and down the eastern seaboard successful." The legal landscape of dam removal and fish passage construction is complex, with a diverse river restoration community working with the state of Maine and federal authorities to find solutions to power generation needs and mandates to address environmental laws such as the Clean Water and Endangered Species Acts (Bowman 2002). In Maine, this process has involved collaboration among diverse interests, such as in the Penobscot River, where negotiations between hydropower and river restoration interests culminated in the removal of two major dams and the installation of fish passage around a third in 2013. In return, the hydroelectric company increased power generation at six other dams on the watershed. One stakeholder described the result: "That's what's really exciting about it to me. Beside the fact that we removed two dams and have fish coming back, just that such a group of diverse people can come together and reach such an agreement, a historical, \$62 million agreement. It really gives me hope for the future of the planet." A smaller collaboration between a local hydroelectric company and restoration advocates on the Sebasticook River was similarly successful, resulting in the installation of a fish elevator, the restoration of a local fishery, and millions of fish migrating upstream. A hydroelectric company employee described the benefit of this collaborative approach as helping to achieve cost-effective success at installing required fish passage equipment: "An economic benefit for us is to have this work successfully. So far it has worked great, and it's not hard when you cooperate with each other." Summarizing the positive relationship, one town official remarked, "We work with them and the end result is that everyone looks like a winner." This collaborative approach to align conservation and economic goals 
stands in stark contrast to similar restoration initiatives that have caused controversy and conflict among groups of stakeholders (Lejon et al. 2009).

Despite general belief in the broad value of river restoration among the diverse stakeholders we interviewed, the process of restoration has not been entirely without conflict, demonstrated by the case of St. Croix River alewives. As in many rivers, 19th century dam construction ended a historically active alewife fishery in the St. Croix River, which forms the U.S. border with Canada. Subsequently, small-mouth bass (Micropterus dolomieu) were introduced into headwater lakes, and a local sportfishing industry developed around these nonnative fish. Believing that increased alewife populations would reduce bass populations, a small group of Maine sportfishing guides successfully blocked river restoration for two decades before restoration interests prevailed. The international nature of this issue, involving the USA and Canada, as well as the Passamaquoddy Indian tribe, which strongly supported restoration of the shared river, resulted in international press coverage (e.g., Sherwood 2013). However, this relatively high-profile conflict stands in stark contrast to the collaborative approach to restoration observed throughout Maine and the minimal local conflict noted by our interviewees.

\section{Ecosystem services and recreation}

Finally, stakeholders pointed to ecosystem services and recreational benefits brought by restored alewife populations. A small percentage of alewives are harvested, allowing the majority of the run to reach its destination and reproduce in upstream lakes, as demonstrated by alewife harvesting data from the Damariscotta River (Fig. 3C). Many pointed to the ecological importance of alewives as forage fish for marine, freshwater, and terrestrial predators throughout this process. One harvester expressed, "Everything eats alewives, so if you have a healthy population, then you have a basis for a very healthy ecosystem from top to bottom." A long-time local resident asserted he has seen a dramatic change in the river, with increases in wildlife: "game fish all the way up to the birds of prey and mammals." One harvester commented that these benefits will stretch into the ocean as well: "We are seeing codfish and haddock again, this is stuff we haven't seen for a long time: inshore pollock, why are they here? They have something to eat."

Stakeholders also commented that increases in alewife populations have resulted in local water quality improvements. Alewives consume freshwater zooplankton; when they migrate back into the ocean, they export phosphorous, one of the major contributors to freshwater algae blooms (U.S. Fish and Wildlife Service (USFWS) 2004). One stakeholder described "an astounding achievement from just one year's worth of alewife reintroduction": visibly improved water quality in a previously "hopelessly culturally eutrophic" local lake. As a result of this success, nearby towns are now considering alewife enhancement programs and river restoration as an alternative to more technical solutions to water quality issues, such as chemical reduction of phosphorous loads through alum introductions, demonstrating the ecosystem services value of historically functioning ecosystems.

Associated with these increases in predators and water quality, stakeholders described enhanced recreational opportunities. One remarked that "restoration has so many tiers. Look at the eagles, ospreys, the great blue heron. Those birds are here for a reason: the fish. That in turn draws bird-watchers, there's another tier." A fish agent was surprised by the increase in tourism, stating, "It's amazing how many visitors we get. Kids and old people taking pictures of eagles, ospreys, and loons." One stakeholder explained the regional significance of the renewal of wildlife: "It goes back to why people go to Maine. They go for places like Acadia, for lobster, for the seacoast, for the mountains, for the vast areas of wilderness, for hunting, for fishing, for Damariscotta Mills to see that big run of fish. The overarching principle of the reasons people come to Maine is they feel like they're going somewhere beautiful and wild, a perception of pristine beauty, this is all part of it."

\section{DISCUSSION AND CONCLUSION}

Placing restoration efforts into a larger social context provides a more realistic evaluation of the range of values associated with restoration than does economic analysis alone. We identified five key benefits of restoring historical alewife fisheries and connectivity in Maine's rivers. Together, these findings can inform historical ecology, SES research and new conservation, and discussions of the value of restoration.

Historical ecology has most often described long-term declines and the shifted baseline of human perceptions that results in a ratcheting down of expectations for natural systems (Pauly 1995). As successful restoration efforts increase (Benayas et al. 2009), there is an opportunity to understand the ways in which the resultant growth in productivity and ecosystem services alter expectations of the value of nature. River restoration and the growth of small-scale municipal alewife fisheries in Maine represent a localized unshifting of baselines, as ecosystems recover and community members begin a process of collective remembering of the value of these ecosystems. Although communities lost the memory of the productive local fisheries that their rivers could support, a cultural connection to these fisheries persisted among some individuals, helping to spark a broader interest in restoring these fisheries. The reported feelings of local empowerment following successful restoration efforts were no doubt propagated by the rapid local recovery of alewife runs and the apparent resilience of this species. In contrast, restoration of other anadromous fish species, including endangered Atlantic salmon, have failed despite hundreds of millions of dollars and decades of restoration efforts, with populations now small fractions of their historical abundances (Limburg and Waldman 2009, Brown et al. 2013).

Although the return of large alewife runs to Maine rivers following restoration is clear, it should not be mistaken for a full recovery to historical baselines. Original population abundances for alewives are unknown (Limburg and Waldman 2009), but these fish were once so numerous that they have been described as the "passenger pigeons of the sea" (Bolster 2006). Along with the ongoing effects of dams, bycatch in offshore herring (Clupea harengus) fisheries poses a major threat; since 1970, alewife landings on the east coast of the USA have declined by $93 \%$, with extirpations in the southern end of their range (Atlantic States Marine Fisheries Commission (AMFC) 2012, Palkovacs et al. 2014). Compared with alewife stocks across the eastern seaboard, Maine's alewives are of lower conservation concern (Palkovacs et al. 2014), but challenges still remain. In this context, the localized 
recovery of alewife runs in Maine rivers - along with growing understanding that restoration efforts can produce a rapid benefit for local communities - represents a small step in the right direction toward alewife population recovery and increased resilience of Maine's fishing communities.

Social-ecological systems research and new conservation have pointed to the need to find solutions that benefit both people and ecosystems. In Maine, this has been demonstrated by restored rivers that have resulted in economic enhancement and fisheries diversification, as well as the nonmarket value associated with ecosystem services and community strengthening in postindustrial towns. Revitalization in postindustrial towns often focuses on repurposing industrial buildings, turning mills into trendy apartment buildings or art museums, and other improvements to the human landscape (Ryznic 2014), but restoration of ecosystems may have a similar effect on community revitalization and engagement. Likewise, the claim that new conservation can broaden the community of conservationists (Tallis et al. 2008, Kareiva and Marvier 2013, Levin 2014) is demonstrated by the diversity of interest groups that describe benefits from Maine river restoration efforts, including fish harvesters, power companies, Native American communities, and more traditional conservationists. This diversity stands in contrast to the commonly polarized political environment of much environmental debate (Lejon et al. 2009, Kahan et al. 2012) and enlarges the scope of possibilities for transformative ecological and social change.

Our interviews suggested a positive feedback among ecological restoration, economic benefit, and pride in community, demonstrating that economic benefits are just a small proportion of the total social benefits. This result contributes to a larger dialog on the value of restoration (Aronson et al. 2010, Petursdottir et al. 2013), pointing to a need to more fully consider the suite of social benefits achieved, stakeholders' views of those benefits, and potential positive feedbacks among benefits. Ultimately, locally successful conservation initiatives, such as these restored fisheries, may enhance the collective ability of both individuals and communities to address larger environmental and social issues, eroding feelings of lack of empowerment, and increasing the ability for positive social and environmental change on a larger scale.

Responses to this article can be read online at: http://www.ecologyandsociety.org/issues/responses. $\mathrm{php} / 7585$

\section{Acknowledgments:}

We are grateful to the stakeholders who were interviewed for their time and insights; Robin Alden, Ted Ames, Jake Krietzler, Lia Morris, Benjamin Neal, and members of the Alewife Harvesters of Maine for useful discussion; Carolyn Hall, Patrick Hurley, Philip Nyhus, and two anonymous reviewers for constructive comments on this manuscript; and Sarah Madronal and AJ Swhartz for preliminary research as part of a Colby College Environmental Studies senior capstone course. Interviews were conducted with the approval of the Colby College Institutional Review Board (IRB
2014-065). L.M. was supported by an Alfred P. Sloan Fellowship for Ocean Sciences (\# FG-BR2013-071).

\section{LITERATURE CITED}

Alden, R. 2011. Building a sustainable seafood system for Maine. Maine Policy Review 20:87-95.

Ames, E. P. and J. Lichter. 2012. Gadids and alewives: structure within complexity in the Gulf of Maine. Fisheries Research. 141:70-78. http://dx.doi.org/10.1016/j.fishres.2012.09.011

Aronson, J., J. N. Blignaut, S. J. Milton, D. Le Maitre, K. J . Esler, A. Limouzin, C. Fontaine, M. P. de Wit, W. Mugido, P. Prinsloo, L. van der Elst, and N. Lederer. 2010. Are socioeconomic benefits of restoration adequately quantified? A meta-analysis of recent papers (2000-2008) in Restoration Ecology and 12 other scientific journals. Restoration Ecology 18(2):143-154. http://dx.doi. org/10.1111/j.1526-100X.2009.00638.X

Atlantic States Marine Fisheries Commission (AMFC). 2012. River herring benchmark stock assessment. Volume 1. Stock Assessment Report No. 12-02, Atlantic States Marine Fisheries Commission, Washington, D.C., USA.

Benayas, J. M., A. C. Newton, A. Diaz, and J. M. Bullock. 2009. Enhancement of biodiversity and ecosystem services by ecological restoration: a meta-analysis. Science 325(5944):11211124. http://dx.doi.org/10.1126/science. 1172460

Berkes, F., T. P. Hughes, R. S. Steneck, J. A. Wilson, D. R. Bellwood, B. Crona, C. Folke, L. H. Gunderson, H. M. Leslie, J. Norberg, M. Nyström, P. Olsson, H. Österblom, M. Scheffer, and B. Worm. 2006. Globalization, roving bandits, and marine resources. Science 311(5767):1557-1558. http://dx.doi.org/10.1126/ science. 1122804

Bolster W. J . 2006. Opportunities in marine environmental history. Environmental History 11:567-597. http://dx.doi. org/10.1093/envhis/11.3.567

Bowman, M. B. 2002. Legal perspectives on dam removal. BioScience 52(8):739-747. http://dx.doi.org/10.1641/0006-3568 (2002)052[0739:LPODR]2.0.CO;2

Bradley, M. E. 2011. Addressing consolidation in the New England groundfish fishery: an examination of multiple management approaches. Thesis, Nicholas School of the Environment, Duke University, Durham, North Carolina, USA.

Brown, J. J., K. E. Limburg, J. R. Waldman, K. Stephenson, E. P. Glenn, F. Juanes, and A. Jordaan. 2013. Fish and hydropower on the U.S. Atlantic coast: failed fisheries policies from half-way technologies. Conservation Letters 6(4):280-286. http://dx.doi. org/10.1111/conl.12000

Cafaro, P., and R. Primack. 2014. Species extinction is a great moral wrong. Biological Conservation 170:1-2. http://dx.doi. org/10.1016/j.biocon.2013.12.022

Crane, J. 2009. "Setting the river free": the removal of the Edwards dam and the restoration of the Kennebec River. Water History 1:131-148. http://dx.doi.org/10.1007/s12685-009-0007-2

Coffin, P. 1855. The memoir and journals of Rev. Paul Coffin. B. Thurston, Portland, Maine, USA. 
Cumming, G. S. 2011. Spatial resilience in social-ecological systems. Springer, New York, New York, USA. http://dx.doi. org/10.1007/978-94-007-0307-0

de Groot, R. S., J. Blignaut, S. van der Ploeg, J. Aronson, T. Elmqvist, and J. Farley. 2013. Benefits of investing in ecosystem restoration. Conservation Biology 27 (6):1286-1293. http://dx.doi. org/10.1111/cobi.12158

Folke, C., S. R. Carpenter, B. Walker, M. Scheffer, T. Chapin, and J. Rockstrom. 2010. Resilience thinking: Integrating resilience, adaptability, and transformability. Ecology and Society 15(4): 20. [online] URL: http://www.ecologyandsociety.org/vol15/iss4/ $\underline{\operatorname{art} 20 /}$

Frank, M. 2011. How industrial power shaped the New England landscape. Pages 269-284 in B. Harrison and R. W. Judd. A landscape history of New England. MIT Press, Cambridge, Massachusetts, USA.

Friedlander, A. M., J. M. Shakeroff, and J. N. Kittinger. 2013. Customary marine resource knowledge and use in contemporary Hawai'i. Pacific Science 67(3):441-460. http://dx.doi.org/10.2984/67.3.10

Gilmour, P. W., R. W. Day, and P. D. Dwyer. 2012. Using private rights to manage natural resources: is stewardship linked to ownership? Ecology and Society 17(3): 1. http://dx.doi. org/10.5751/es-04770-170301

Gonzalez, J. A., C. Montes, J. Rodrigues, and W. Tapia. 2008. Rethinking the Galapagos Islands as a complex social-ecological system: implications for conservation and management. Ecology and Society 13(2): 13. [online] URL: http://www.ecologyandsociety. org/vol13/iss2/art13/

Goodman, L. A. 1961. Snowball sampling. The Annals of Mathematical Statistics 32(1):148-170. http://dx.doi.org/10.1214/ aoms/1177705148

Hall, C. J., A. Jordaan, and M. G. Frisk. 2011. The historic influence of dams on diadromous fish habitat with a focus on river herring and hydrologic longitudinal connectivity. Landscape Ecology 26:95-107. http://dx.doi.org/10.1007/s10980-010-9539-1

Humphries, P., and K. O. Winemiller. 2009. Historical impacts on river fauna, shifting baselines, and challenges for restoration. BioScience 59(8):673-684. http://dx.doi.org/10.1525/bio.2009.59.8.9

Kahan, D. M., E. Peters, M. Wittlin, P. Slovic, L. L. Ouellette, D. Braman and G. Mandel. 2012. The polarizing impact of science literacy and numeracy on perceived climate change risks. Nature Climate Change 2:732-735. http://dx.doi.org/10.1038/nclimate1547

Kahnle, A., and K. Hattala. 2010. Hudson River American shad: an ecosystem-based plan for recovery. New York Department of Environmental Conservation, New York, New York, USA. [online] URL: http://www.dec.ny.gov/docs/remediation_hudson_pdf/ shadrecoveryplan.pdf

Kareiva, P., and M. Marvier. 2013. What is conservation science? Bioscience 62(11):962-969.

Lejon, A. G. C., B. M. Renofalt, and C. Nilsson. 2009. Conflicts associated with dam removal in Sweden. Ecology and Society 14 (2):4. [online] URL: http://www.ecologyandsociety.org/vol14/ iss $2 / \operatorname{art} 4 /$
Lewis, L. Y., C. Bohlen, and S. Wilson. 2008. Dams, dam removal and river restoration: a hedonic property value analysis. Contemporary Economic Policy 26(2):175-186.

Levin, P. 2014. New conservation for the Anthropocene Ocean. Conservation Letters 7(4):339-340. http://dx.doi.org/10.1111/ $\underline{\text { conl. } 12108}$

Lichter, J., H. Caron, T. S. Pasakarnis, S. L. Rodgers, T. S. Squiers Jr., and C. S. Todd. 2006. The ecological collapse and partial recovery of a freshwater tidal ecosystem. Northeastern Naturalist 13:153-178. http://dx.doi.org/10.1656/1092-6194(2006)13[153: TECAPR]2.0.CO;2

Limburg, K. E., and J. R. Waldman. 2009. Dramatic declines in North Atlantic diadromous fishes. BioScience 59(11):955-965. http://dx.doi.org/10.1525/bio.2009.59.11.7

MacKinnon, J. B 2014. Choice without memory: uncovering the narrative potential of historical ecology. Pages 265-276 in J. N. Kittinger, L. McClenachan, K. B. Gedan and L. K. Blight. 2014. Marine historical ecology in conservation: applying the past to manage the future. University of California Press, Oakland, California, USA.

Maine Department of Marine Resources(DMR). 2009. Kennebec River anadromous fish restoration. DMR, Augusta, Maine, USA. [online] URL: http://www.maine.gov/dmr/searunfish/reports/ KHDGreport2009.pdf

Maine Department of Marine Resources (DMR). 2011. Kennebec River diadromous fish restoration project, annual progress report. DMR, Augusta, Maine, USA.

Marsh, H., G. De'ath, N. Gribble, and B. Lane 2005. Historical marine population estimates: triggers or targets for conservation? The dugong case study. Ecological Applications 15:481-492. http://dx.doi.org/10.1890/04-0673

McClenachan, L., F. Ferretti, and J. K. Baum. 2012. From archives to conservation: why historical data are needed to set baselines for marine animals and ecosystems. Conservation Letters 5:349-359 http://dx.doi.org/10.1111/j.1755-263x.2012.00253. $\underline{\mathrm{X}}$

McClenachan, L., and J. Kittinger. 2013. Multicentury trends and the sustainability of coral reef fisheries in Hawaii and the Florida Keys. Fish and Fisheries 14:239-255

McClenachan, L., B. P. Neal, D. Al-Abdulrazzak, T. Witkin, K. Fisher, and J. N. Kittinger. 2014. Do community supported fisheries (CSFs) improve sustainability? Fisheries Research 157: 62-69.

McClenachan, L. G. O’Connor, and T. Reynolds. 2015. Adaptive capacity of co-management systems in the face of environmental change: the soft-shell clam fishery and invasive green crabs in Maine. Marine Policy 52(1):26-32.

Miller, B., M. E. Soulé, and J. Terborgh. 2014. "New conservation" or surrender to development. Animal Conservation 17(6):509-515. http://dx.doi.org/10.1111/acv.12127

Overton, A. S. 2013. In a perfect river: the historical contributions of river herring and shad to commercial and recreational fisheries and the culture in North Carolina. In Proceedings, American 
Fisheries Society 143rd Annual Meeting, 8-14 September 2013, Little Rock, Arizona, USA.

Palkovacs, E. P., D. J. Hasselman, E. E. Argo, S. R. Gephard, K. E. Limburg, D. M. Post, T. F. Schultz, and T. V. Willis. 2014. Combining genetic and demographic information to prioritize conservation efforts for anadromous alewife and blueback herring. Evolutionary Applications 7(2):212-226. http://dx.doi. org/10.1111/eva.12111

Pauly, D. 1995. Anecdotes and the shifting baseline syndrome of fisheries. Trends in Ecology and Evolution 10(10):430. http:// dx.doi.org/10.1016/S0169-5347(00)89171-5

Petursdottir, T., O. Arnalds, S. Baker, L. Montanarella, and A. Aradottir. 2013. A social-ecological system approach to analyzing stakeholders' interactions within a large-scale rangeland restoration program. Ecology and Society 18(2): 29. http://dx.doi.org/10.5751/ES-05399-180229

Rosenberg, A. A., W. J. Bolster, K. E. Alexander, W. B. Leavenworth, A. B. Cooper, and M. G. McKenzie. 2005. The history of ocean resources: modeling cod biomass using historical records. Frontiers in Ecology and the Environment 3 (2):78-84. http://dx.doi.org/10.1890/1540-9295(2005)003[0078: THOORM]2.0.CO;2

Rounsefell, G. A. and L. D. Stringer. 1945. Restoration and management of the New England alewife fisheries with special reference to Maine. Transactions of the American Fisheries Society 73 (1):394 424. http://dx.doi.org/10.1577/1548-8659 (1943)73[394:RAMOTN]2.0.CO;2

Ryznic, J. 2014. Post-industrial New England: repairing the voids. Thesis, School of Architecture and Design, University of Massachusetts, Amherst, Massachusetts, USA.

Saunders, R., M. A. Hachey, and C. W. Fay. 2006. Maine's diadromous fish community: past, present, and implications for Atlantic salmon recovery. Fisheries 31(11):537-547. http:// dx.doi.org/10.1577/1548-8446(2006)31[537:MDFC]2.0.CO;2

Severson, K. 2008. Celebrating the shad by sparing it. New York Times 20 April. [online] URL: http://www.nytimes. com/2008/04/30/dining/30shad.html? $\mathrm{r}=0$

Sherwood, S. 2013. Fish win: Maine about-face lets alewives return to Canada border river. The World, PRI. [online] URL: http://www.pri.org/stories/2013-07-09/fish-win-maine-about-facelets-alewives-return-canada-border-river

Smith, H. H. 1896. Notes on the extent and condition of the alewife fisheries of the United States in 1896. US Commission of Fish and Fisheries. Washington, D.C., USA.

Soulé, M. 2013. The "New Conservation." Conservation Biology 27(5):895-897. http://dx.doi.org/10.1111/cobi.12147

Steneck, R. S., T. P. Hughes, J. E. Cinner, W. N. Adger, S. N. Arnold, F. Berkes, S. A. Boudreau, K. Brown, C. Folke, L. Gunderson, P. Olsson, M. Scheffer, E. Stephenson, B. Walker, J. Wilson, and B. Worm. 2011. Creation of a gilded trap by the high economic value of the Maine lobster fishery. Conservation Biology 25(5):904-912. http://dx.doi.org/10.1111/ j.1523-1739.2011.01717.x
Tallis, H., P. Kareiva, M. Marvier, and A. Chang. 2008. An ecosystem services framework to support both practical conservation and economic development. Proceedings of the National Academy of Sciences 105(28):9457-9464. http://dx.doi. org/10.1073/pnas.0705797105

Thara Srinivasan, U., W. W. L. Cheung, R. Watson, and U. R. Sumaila. 2010. Food security implications of global marine catch losses due to overfishing. Journal of Bioeconomics 12(3):183-200. http://dx.doi.org/10.1007/s10818-010-9090-9

United States Fish and Wildlife Service(USFWS). 2004. All about Maine alewives. USFWS, Washington, D.C., USA. [online] URL: http://www.fws.gov/gomcp/pdfs/alewife $\% 20$ fact $\% 20$ sheet.pdf

Watts, D. H. 2012. Alewife: a documentary history of the alewife in its native habitat in Maine and Massachusetts. Poquanticut Press, Augusta, Maine, USA.

Yoshiyama, R. M., F. W. Fisher, and P. B. Moyle. 1998. Historical abundance and decline of Chinook salmon in the Central Valley Region of California. North American Journal of Fisheries Management 18(3):487-521. http://dx.doi.org/10.1577/1548-8675 (1998)018<0487:HAADOC>2.0.CO;2 


\section{Appendix 1. Primary interview questions.}

Personal involvement

- What is your role within river restoration/the alewife fishery in your community?

Local restoration

- How would you characterize local river restoration efforts? Who has been involved? Have there been any local conflicts?

- Have you noticed changes in alewife abundances?

- Have there been any notable developments in local alewife fisheries?

Perception of benefits and community involvement

- Have you seen your community benefit from the restored river and/or alewife fishery? If yes, in what ways?

- How would you characterize community involvement with restoration and/or the alewife fishery?

- Does your community sponsor any events that recognize the fishery or river restoration? If yes, how would you characterize community involvement in those events?

- What do you see in the future for the alewife fishery in your town? What challenges remain?

Town specific information (asked of town clerks and fish agents):

- How long has the alewife fishery existed in your town?

- How have landings changed over time?

- How are fishing rights leased in your town?

- How is revenue divided between the harvester and the municipality?

- Have there been any recent changes to the alewife fishery in your town? 